QL

685.5

N54A36

1939

BIRDS 



\title{
BIRDS OF
}

\section{EASTERN/NEWFOUNDLAND}

\author{
By \\ JOHN W. ALDRICH \\ and \\ DAVID C. NUTT
}

SCIENTIFIC PUBLICATIONS

of the

CLEVELAND MUSEUM OF NATURAL HISTORY

Vol. IV, No. 2, pp. 13-42

Issued: December 28, 1939

Cleveland, Ohio 



\title{
SCIENTIFIC PUBLICATIONS
}

OF THE

\section{CLEVELAND MUSEUM OF NATURAL HISTORY}

\begin{tabular}{lll}
\hline \hline VOL. IV ISSUED, DECEMBER 28, 1939 & No. 2 \\
\hline
\end{tabular}

\author{
BIRDS OF EASTERN NEWFOUNDLAND \\ BY \\ JoHN W. ALdrich \\ AND \\ David C. Nutt
}

\section{INTRODUCTION}

Eastern Newfoundland has been explored by only a few ornithologists even up to the present day and little is known about its bird life. Therefore, it was indeed a matter of good fortune that the junior author was enabled to undertake a brief exploration of this region while a member of the Robert A. Bartlett Greenland Expeditions of 1937, 1938, and 1939. A total of 13 days in early July and early September were spent ashore on the Avalon Peninsula, while another 25 days during the 3 years were consumed in cruising along the south and east coasts of Newfoundland on the way to and from Labrador and points north. During this time a record was kept of all birds encountered and, wherever possible, specimens were collected.

The coastal region of eastern Newfoundland is characterized by barren, rocky tundra and low scrubby spruce. Vegetation is scarce except in the hollows where practically all of the soil accumulates. High grassy flats above Brigus are partially covered with a mat of low wiry shrubs, and are bounded on the harbor and seaward sides by rocky cliffs.

Farther inland the bold coastal features blend into a less rugged landscape 200-300 feet above sea level. At Hodge Water, a region of glacial drift, 11 miles inland from Brigus, there is a small chain of lakes surrounded by low rolling hills. The landscape is covered for the most part by a dense second growth of spruce with occasional tamaracks. The forest is broken occasionally by barren or grassy open spaces. Bogs are numerous. Blueberry in the drier situations 
and sweet gale in the wetter places form the chief ground cover. Our party collected in this region from July 7 to 9, 1938.

Four days in early September 1938 and 1939 and 2 days in early July 1939 were spent at Makinson's Grove, known also as the Gould. Makinson's Grove is 6 miles inland and the only area in the vicinity of Brigus where any sizable timber occurs. It is almost entirely spruce with a few tamaracks and an occasional stunted maple. All the trees are covered with a scaly lichen and usnea moss is commonly seen festooning the branches.

At Makinson's Grove the comparatively great diversity of habitat makes it better bird country than most other sections visited. There are wet areas covered by low bog shrubs, the home of the swamp sparrow. One section is open, grazed land that blends into a dense forest toward the north. In the bottom of the valley flows a shallow but swift stream.

During the time ashore in Newfoundland an almost continuous high wind made collecting and observing difficult. In July of 1939 it rained the entire time ashore thus further handicapping operations. In the areas visited bird life was abundant, but the number of individual species of land birds seemed to be comparatively restricted. Only 37 species were recorded during the 13 days of observation ashore.

Specimens collected by the junior author, assisted by Raymond Hellmann and Samuel Bartlett number 82 and comprise 20 species. The discovery of 2 previously undescribed subspecies in this comparatively small collection gives some idea of the little known condition of the bird life of this region.

G. K. Noble (1919) in his illuminating paper on geographic variation based on a collection from the western part of the island concludes that Newfoundland is a region where the differentiation of dark colored races is beginning to take place.

The results of our studies confirm this opinion. It would seem that this darkening, noticeable in the west, becomes increasingly more marked in the eastern part of the island. This was found to be the case particularly with the Savannah sparrow, robin, and black-capped chickadee.

The only previous publications dealing definitely with the ornithology of eastern Newfoundland seem to be those of E. A. Brooks 
(1936) who spent 9 days in the summer of 1932 studying the birds of the Avalon Peninsula, and K. B. Rooke (1935) who worked chiefly in the Grand Falls region, near the center of the Island, but also obtained some interesting records from the Avalon Peninsula. It is, therefore, a comparatively easy matter to bring the information on the birds of eastern Newfoundland up to date, and at the same time add materially to the knowledge of the distribution, abundance, and geographic variation of a few species found in this interesting part of North America.

We are indebted to Mr. Gower Rabbitts, of the Department of Natural Resources of Newfoundland, for the permits to collect birds there; to Captain Robert A. Bartlett whose kindness and patience made the ornithological work on the Expedition possible; and to Dr. Harry C. Oberholser who has very generously gone over the entire manuscript and favored us with invaluable criticism and advice.

\section{BIRDS KNOWN TO OCCUR IN EASTERN NEWFOUNDLAND}

Gavia immer immer (Brünnich). Common Loon.

Local name: Loo.

On the 1938 expedition loons were heard during both nights spent on the chain of lakes at Hodge Water. Brooks (1936) records seeing only one during the nine days of his stay on the Avalon Peninsula, while Rooke (1935) found 1 or more loons on the lakes of the Grand Falls region in the interior of Newfoundland.

Puffinus griseus (Gmelin). Sooty Shearwater.

Local name: Black Hagdown.

Off Bonavista Bay and near the Funk Islands 8 sooty shearwaters were seen on July 12 and 13, 1938. On July 7, 1939, there were a few seen with a large flock of greater shearwaters at the mouth of Conception Bay. In September 1938, none were recorded; but 3 were seen on August 30 and 31, 1939, while coming toward the Newfoundland Coast near Cape Bonavista. It would seem that the sooty shearwater is of irregular occurrence off Eastern Newfoundland. 
Puffinus gravis (O'Reilly). Greater Shearwater. Local name: Hagdown.

The greater shearwater is a common bird off the south and east coast of Newfoundland, especially so on the fishing banks. A fishing schooner is often seen surrounded by a cloud of "Hagdowns". On July 7, 1939, a flock, estimated at over 800 , was encountered at the mouth of Conception Bay. These birds are common along the Labrador coast. In early September most of the greater shearwaters appear to have shifted southward and are more common on the Grand Banks and to the westward. However, so irregular is the occurrence of this species that one day thousands are to be seen and the next day none at all.

Fulmarus glacialis glacialis (Linnaeus). Atrantic Fulmar.

Local name: Noddy.

Going north the fulmar was first met with off Cape St. Mary's in southern Newfoundland, where two were observed on July 5, 1939. It became increasingly common farther north, particularly off the Funk Islands where a large number were observed on July 13, 1938. In 1939 our party found it uncommon until well out to sea between Newfoundland and southern Greenland. On the return voyages late in the summer fulmars were never close to the shore of eastern Newfoundland.

Practically all fulmars along the Newfoundland coast were of the light phase with only a very few that might be considered as even intermediate between the light and dark plumages.

Oceanodroma leucorhoa leucorhoa (Vieillot). Leach Petred. Local name: Carey chick, or Mother Carey's chick.

The Leach petrel is a common bird off the east coast of Newfoundland, especially about the Funk Islands near which a specimen was collected July 18, 1937, and where the Newfoundland sailors say that it breeds. Lucas (1890) found them breeding at the Penguin Islands 10 miles north-west of Cape Freels in the summer of 1887. 
It is interesting to note that on calm days, petrels are rarely observed, whereas on days having a little wind and sea, many are to be seen. It seems to be easier for them to fly in the wind using the up-drafts caused by the waves, as do also the shearwaters. On foggy nights Leach petrels fly close to the vessel and even come aboard.

\section{Moris bassana (Linnaeus). GanNET.}

Gannets were often seen off the south and east coasts of Newfoundland and were especially common off Cape St. Mary's, where there is a breeding colony estimated as 4000 pairs in 1934 by WynneEdwards (1935). This is the second largest American colony known today according to Gilliard (1937) who discovered another Newfoundland gannet colony on Funk Island. Gilliard states that Jacques Cartier, the discoverer of Funk Island, recorded the gannet as breeding there profusely at the time of his visit in June 1534 . Since, however, Lucas (1890) and others failed to find gannets breeding on Funk Island, Gilliard concluded that this species had re-established itself there in comparatively recent times. He found 7 pairs there in June 1936.

Gross (1937) reports that he saw no gannets north of the Straits of Belle Isle while on the Bowdoin-MacMillan Arctic Expedition of 1934. And Austin (1932) says that there is not a single shred of evidence to show that the species has ever occurred north of the Straits of Belle Isle. There is now plenty of evidence to that effect, for on our return voyage in 1938, gannets were recorded 150 miles north of Belle Isle at Bulldog Island (Lat. $54^{\circ} 38^{\prime} \mathrm{N} ., 57^{\circ} 02^{\prime}$ W.) where 3 were seen on August 31. Early in the morning of September 1, the boatswain saw a flock of 10 or 12, and later that day the junior author saw 2 more off Round Hill. From then on down the coast of Labrador and Newfoundland they were fairly common, especially near Cape Broyle where on September 8, 1938, many flocks, including one of 30 and one of 100 birds, were seen. The natives of Square Island, 45 miles north of Belle Isle, Labrador, reported that they had seen numerous gannets during the summer of 1938. 
Phalacrocorax (sp.?). Cormorant.

Local name: Shag.

On August 31, 1937, numerous cormorants were seen in Stag Harbor Run, between Fogo Island and the mainland, but whether the species was Phalacrocorax auritus or $P$. carbo could not be determined.

Butorides virescens virescens (Linnaeus). EASTRRN GreEN HERON.

A specimen of the green heron from Haricourt, St. Mary's Bay, Avalon Peninsula was given to Rooke for the British Museum by J. R. Ewing of St. John's. However, in the field none were observed by Rooke (1935), Brooks (1936) or our party.

\section{Botaurus lentiginosus (Montagu). American Bittern.}

An American bittern was seen at Hodge Water on July 8 and 9, 1938, and another at Makinson's Grove on September 6, 1938.

Ixobrychus exilis exilis (Gmelin). EASTERn LeAst Bittern.

A specimen of the least bittern from near St. John's, in the possession of Mr. J. R. Ewing, was examined by Rooke (1935).

Branta canadensis canadensis (Linnaeus). Common Canada Goose.

Rooke (1935) reports that this species breeds regularly in the interior of eastern Newfoundland where undisturbed. He saw 2 in the Grand Falls region August 15 that acted as if they had young.

Anas rubripes rubripes Brewster. Red-Legged Black Duck.

Although unrecorded on our expeditions, Brooks (1936) saw a flock of 6 black ducks flying over a pond at Salmonier on the Avalon Peninsula. From other literature it would appear that this species is, in Newfoundland, more common inland than along the coast. 
Glaucionetta clangula americana (Bonaparte). AMERICAN GoLden-eye.

Rooke (1935) saw a few of these ducks in the Grand Falls region in the interior of Newfoundland, but the species is unrecorded by either Brooks (1936) or our party.

Accipiter striatus velox (Wilson). Sharp-shinned Hawk.

One was seen at Makinson's Grove pursuing a flock of Crossbills on September 6, 1938, and again on September 1, of the following year.

Pandion haliaëtus carolinensis (Gmelin). American Osprey.

An osprey was seen by Brooks (1936) on August 5 near Placentia, and this species is reported by Rooke (1935) as not uncommon in the Grand Falls region.

Falco columbarius columbarius Linnaeus. EAstern Pigeon Hawk.

One of these little falcons was seen at "Frog Marsh" near Brigus in September 1937, and the residents say that 1 or 2 individuals are usually to be found there. On September 2, 1938 a flock of eight were seen above the rocky hills near Brigus. Although Brooks (1936) records only 2 pigeon hawks and Rooke (1935) only 1 individual, it would seem that this species is the most common hawk in eastern Newfoundland.

Cerchneis sparveria sparveria (Linnaeus). EAstern Sparrow HAwK.

Rooke (1935) saw a small hawk almost certainly of this species, near St. John's on August 9, 1934.

Lagopus lagopus alleni Stejneger. Allen Ptarmigan.

Lagopus rupestris welchi Brewster. Weich Ptarmigan.

Local name for both species: Pa'tridge.

Brooks (1936) reports seeing specimens of both species of 
ptarmigan in the Museum at St. John's and assumes that they were locally taken. He was also told by "competent nature observers" that both species are common in "the Barrens". Most natives do not distinguish between the 2 species but said that "pa'tridges" were common near Brigus. Rooke (1935) quoted fire wardens of the Great Rattling Brook region in the interior of Newfoundland as saying that ptarmigan were numerous in winter there.

Porzana carolina (Linnaeus). Sora.

A specimen from the Avalon Peninsula, given to Rooke (1935) for the British Museum by J. R. Ewing, is the only record from Eastern Newfoundland.

Vanellus vanellus (Linnaeus). Lapwing.

Brewster (1906) records one in Newfoundland in 1906, and Ingersol (1928) records seeing many after a spell of easterly gales in 1927. Although no records are definitely ascribed to eastern Newfoundland, it seems that these wanderers from Europe would perforce first land there.

Capella gallinago delicata (Ord). Wilson SnIPE.

This snipe is fairly common in boggy places on the Avalon Peninsula. While our party was camped at Hodge Water in July 1938 one was heard "bleating" overhead at almost all hours of the day and night, as was also the case in July 1939 at Makinson's Grove.

Phaeopus borealis (Forster). Eskimo Curlew.

It is within the memory of many residents of Brigus that on certain fall days "droves" of Eskimo Curlew would come to the high flats above the town, even darkening the sky with their great numbers. There seems to be no record of when they became extirpated there.

Actitis macularia (Linnaeus). SPOTTED SANDPIPER.

Local name: Beachy bird.

Spotted sandpipers are fairly common on the Avalon Peninsula. Brooks (1936) records several. One was seen by our party in 
Brigus Harbor July 7, 1938, and on July 6, 1939, a pair was found nesting at Makinson's Grove. The nest was on a dry hillside covered with blueberry bushes about 20 feet above the level of a stream.

\section{Totanus melanoleucus (Gmelin). Greater Yellow-Legs.}

Local name: Twilick.

This is a common bird in the lake regions of the Avalon Peninsula. Many were seen and heard at Hodge Water where a single specimen was collected July 9, 1938. One was seen in a small pond near Brigus early in September 1937.

\section{Pisobia minutilla (Vieillot). Least Sandpiper.}

Local name: Beachy-bird.

One bird, seen at Hodge Water, as far as we know is the only definite record of the least sandpiper for the region. Rooke (1935) states that he saw a small flock of waders on Conception Bay, September 11, which he took to be this species.

\section{Phalaropus fulicarius (Linnaeus). Red Phalarope.}

A specimen of the Red Phalarope in breeding plumage in the possession of J. R. Ewing of St. John's was examined and reported by Rooke (1935). It is said to have been taken on Avalon Peninsula. Two were seen by our party on September 4, 1939, out of sight of land, south of St. Mary's Bay.

\section{Lobipes lobatus (Linnaeus). Northirn Phalarope.}

Local name: Gale bird.

In the early part of September on the return voyages these little phalaropes were fairly common all along the east coast of Newfoundland, especially in the vicinity of Cape Race, where on September 8,1938 , some 200 were seen swimming about in small flocks. 
Stercorarius pomarinus (Temminck). Pomarine Jakger.

Local name: Bosun-bird.

Five Pomarine Jaegers were seen off Cape St. Mary's on July 5, 1938, the only time the species was encountered in Newfoundland waters.

Stercorarius parasiticus (Linnaeus). Parasitic JaEger.

Local name: Bosun-bird, Marlin Spike.

On July 12, 1938, off Bonavista Bay, 2 flocks of 20 and 8 birds respectively flew about the vessel for a short time. On August 30, 1939, near the Funk Islands, a flock of 30 stayed in the wake of the vessel for some time and on the following day a few were still present. The Parasitic Jaeger is by no means uncommon off eastern Newfoundland, but it is of decidedly irregular occurrence.

Catharacta skua Brünnich. Northern SkUA.

Local name: Sea hen.

Off Cape Broyle, on July 6, 1938, a number of skuas paid the vessel a visit. A lone bird was observed on August 30, 1939, near the Funk Islands, and again a single individual was seen on September 5 while over St. Pierre Bank. The skua is apparently not common off the coast of eastern Newfoundland, and also is of decidedly irregular occurrence.

Larus hyperboreus hyperboreus Gunnerus. Glaucous Gull. Local name: Burgomaster, Minister Gull.

A few individuals were seen in Brigus harbor but more near Cape St. Francis on September 3, 1939. On the whole this big gull is not very common on the east coast of Newfoundland.

\section{Larus marinus Linnaeus. Great Black-backed Gull.}

Local name: Saddleback.

Only a few black-backs were seen among the gulls in eastern Newfoundland where they are apparently uncommon. A few were seen in Brigus harbor, and a small number near Cape St. Francis. 
Larus argentatus smithsonianus Coues. American Herring GuLl.

Local name: Sea Gull. Gull.

These gulls were observed commonly off the southeast coast, especially near Cape St. Francis where they appeared to be nesting on the cliffs. A few were always about Brigus harbor, and about a half dozen were observed inland at Hodge Water and Makinson's Grove. Rooke (1935) also found them in the interior on the Exploits River near Grand Falls. Numbers of young herring gulls were seen around Brigus in the fall of 1939.

Rissa tridactyla tridactyla (Linnaeus). Atrantic Kittiwake Local name: Tickle-else.

Kittiwakes are fairly common, but not known to breed in eastern Newfoundland. On July 7, 1939, 25 of these birds were observed in the mouth of Conception Bay and at almost all other times scattered individuals were in evidence. Hoyes Lloyd (1939) reports that a kittiwake banded in northwestern Russia was taken near Little Fogo Island, Newfoundland, September 20, 1937.

Sterna hirundo hirundo Linnaeus. Common Tern.

Local name: Pietrie.

A few terns were occasionally seen from the vessel along the eastern coast of Newfoundland, but it was usually impossible to determine the species. On September 3, 1938, when near the Funk Islands, and on September 3, 1939, off Bay of Bulls, common terns ( 2 birds in each case) were positively identified.

Sterna paradisaea Brünnich. Arctic Tern.

Lucas (1890) found Arctic terns breeding in large numbers on Funk Island in 1887. Their young and eggs in an advanced stage of incubation were scattered from one end of the island to the other. Lucas calls attention to the fact that not a single specimen of the common tern was noticed despite the assertion of Stuvitz in 1844 that he was "surprised at the abundance of the Arctic and 
common tern" on Funk Island. The difficulty of distinguishing between the common and Arctic tern in the field leaves the status of their comparative abundance in eastern Newfoundland still in doubt.

\section{Plautus impennis (Linnaeus). Great Auk.}

Lucas (1890) believed that Funk Island 32 miles off the east coast of Newfoundland was the chief breeding ground of the great auk in North America and that the species survived there long after being extirpated in other more accessible localities. Furthermore there seems to be no evidence as yet that the great auk bred at any locality in eastern Newfoundland except Funk Island.

Alca torda Linnaeus. Razor-billed Auk.

Two were seen on July 8, 1939, near the Funk Islands where Lucas (1890) found them numerous. A few are said to still breed there.

Uria lomvia lomvia (Linnaeus). BrünNich Murre.

Local name: Baccelieu Bird or Turre.

Murres of this species are not uncommon off the east coast of Newfoundland in summer. At least a few scattered individuals were seen every day in that region. On July 13, 1938, when near the Funk Islands where Lucas (1880) found these murres breeding, and Gilliard (1937) estimated 10,000 breeding pairs, 20 were recorded by our party in a 2-hour period. Many were seen near Cape Spear on July 3, 1939. These murres are said to breed on Baccelieu Island, whence the local name for this species, but there never seemed to be a great number there. The residents say that they are more common in the winter months.

Alle alle (Linnaeus). Dovexie.

Local name: Bull-bird or Little Auk.

One was seen swimming near the vessel off Cape Broyle on July 6,1938 , but the species is apparently rare anywhere along the east 
coast of Newfoundland in the summer. It is said by the natives to be a common winter resident in Conception Bay.

Cepphus grylle grylle (Linnaeus). Black Guillemot.

Local name: Pigeon, or Sea Pigeon.

Rooke (1935) states that he saw 2 off St. John's. No guillemots were recorded by our party, however, in the 3 years of observation off the eastern coast, despite the fact that a large breeding colony is reported by Wynne-Edwards (1935) at Cape St. Mary's. The natives report it as common in the winter at which time it stays in the open water beyond the harbor ice.

\section{Fratercula arctica arctica (Linnaeus). Atrantic Puffin.}

Local name: Sea parrot.

The Puffin is locally common off the eastern coast. It appeared to be breeding near Cape Broyle where great numbers were seen July 6, 1938. Eight individuals were encountered in Trepassy Bay on July 3, 1939, and many were found near Cape Spear later the same day. A few were seen on July 7 at the mouth of Conception Bay. Lucas (1890) found them breeding in great numbers on Funk Island in the summer of 1887 . Their burrows were numerous in the thick soil on the top of the island which was formerly the breeding ground of the great auk. The excavated bones of these extinct auks were usually found around the entrances to puffin burrows.

Zenaidura macroura carolinensis (Linnaeus). EASTERN Mourning Dove.

According to Lewis (1922) a pair was shot at Trepassy on October 1, 1921, after a severe southerly storm.

Bubo virginianus neochorus Oberholser. Newroundiand HoRNed OwL.

Several of these large owls were seen and heard by Rooke (1935) in the Grand Falls region where he collected a single specimen. The species is unrecorded by either Brooks (1936) or our party, however. 
Nyctea nyctea (Linnaeus). SNowy OwL.

Rooke (1935) reports 1 seen in the Grand Falls region on August 25,1934 , that he judged to be an early migrant. He states that it is known to occur in Newfoundland as a winter resident.

Megaceryle alcyon alcyon (Linnaeus). EAstern Belted KingFISHER.

Brooks (1936) records several at Bowring Park, St. John's, but none were observed by our party. The natives said that it was very rare near the coast but could be found inland.

\section{Colaptes auratus luteus Bangs. Northern Flicker.}

It would seem that the flicker is the most common woodpecker in eastern Newfoundland. One was heard at Hodge Water on July 8, 1938, and there were always a few to be seen at Makinson's Grove. One nesting pair was observed on July 5, 1939. The nest was found in a sawed off spruce stump $31 / 2$ feet above the ground. In it were 6 recently hatched young.

The single female specimen in fresh autumn plumage collected on September 2, 1938, measured as follows: wing, $153.5 \mathrm{~mm}$.; tail, 99.5; culmen, not measurable (broken); tarsus, 28; middle toe without claw, 23.5. The size seems to place the bird as Colaptes a. luteus rather than as $C$. a. borealis.

Sphyrapicus varius atrothorax (Lesson). NORTHERn YeLLowBELLIED SAPSUCKER.

Rooke (1935) obtained a single specimen on Beaver Mountain on August 12, and saw evidence of others in the presence of their workings on birches.

Dryobates villosus terraenovae Batchelder. NewfoundLAND HAIRY WoOdPECKER.

Recorded as common by Rooke (1935) in the Grand Falls region, but although the type specimen comes from Placentia on the Avalon 
Peninsula, it is seemingly uncommon there. Brooks (1936) saw but 2 at Calinet and our party recorded it only on September 2, 1939, at Makinson's Grove.

Dryobates pubescens microleucus Oberholser. NEwfoundLAND DOWNY WOODPECKER.

This species is apparently rare in eastern Newfoundland since it is entirely unrecorded by either Rooke (1935) or our party, while Brooks (1936) saw but 1 in Bowering Park, St. John's.

Picoïdes tridactylus bacatus Bangs. American Three-toed WOODPECKER.

A single specimen taken by Rooke (1935) on Beaver Mountain August 12, 1934, is the only record of this species in eastern Newfoundland.

Empidonax flaviventris (Baird and Baird). YeLlow-BELlied Flycatcher.

Brooks (1936) saw 1 pair and heard others in eastern Newfoundland and a specimen from the Avalon Peninsula was given to Rooke (1935) by J. R. Ewing of St. John's. The species is apparently uncommon on the Avalon Peninsula since it was not observed by our party.

Nuttallornis borealis cooperi (Nuttall). EAstern Olive-sided Flycatcher.

Rooke (1935) records several for Beaver Mountain August 12, 1934, where a specimen was obtained by him.

Otocoris alpestris alpestris (Linnaeus). NORTHERn Horned LARK.

Local name: Mud Lark.

This lark was common on the exposed rocky ridges of the Avalon Peninsula. Numerous individuals were seen on the high flat 
tundra above Brigus harbor. According to Rooke (1935) it is apparently absent from the open country of the interior.

The single adult male breeding specimen collected on July 6 , 1937, is definitely the large, yellow-browed alpestris, although noticeably paler above than examples in comparable plumage from Cape Domino, Labrador.

Iridoprocne bicolor (Vieillot). T $\mathrm{T}_{\mathrm{REE}}$ Swallow.

Local name: Martin.

Brooks (1936) writes that he saw 7 or 8 over Long Pond and Rooke (1935) saw what he took to be migrating flocks in the Grand Falls region during August, but our party failed to record it in July or September. The "martins" are familiar to the residents of the Brigus region who tell of seeing thousands in August flying over the small ponds.

Perisoreus canadensis sanfordi Oberholser. Newroundland JAY.

Local name: Jay.

This jay is a common, well known resident in eastern Newfoundland. A single specimen was collected by our party at Makinson's Grove, September 1, 1939.

Cyanocitta cristata bromia Oberholser. Northern Blue Jay.

Rooke (1935) examined a mounted specimen in the possession of J. R. Ewing, taken near St. John's.

Corvus corax principalis Ridgway. Northern Raven.

Two ravens were recorded from the interior by Rooke (1935) but there are no records for the Avalon Peninsula. 
Corvus brachyrhynchos brachyrhynchos Brehm. EASTERN Crow.

Local name: Crow.

Crows are common in the vicinity of Brigus, but like their more southern relatives are very wary.

Penthestes atricapillus bartletti, * subsp. nov. NewfoundLAND Black-Capped Chickadee.

Local name: Pig-a-pee.

Subspecific characters. - Similar to Penthestes atricapillus atricapillus but darker and more brownish above, and darker buff on flanks and under tail-coverts. White edgings to wing and tail feathers narrower. Bill larger. In color nearer to $P$. a. occidentalis than to any other known race but much larger.

Measurements.-Adult male ( 8 specimens in fresh autumn plumage from Newfoundland): wing, 63.5-68 (average 66.12) mm.; tail, 62-63.5 (62.68); total culmen, 10-11 (10.57); tarsus, 16.5-18 (17.25). Adult female ( 6 specimens in worn breeding plumage from Newfoundland): wing, 61-64 (average 62.33) mm.; tail, 56-60 (58.20); total culmen, 9.5-11 (10.17); tarsus 16-17.5 (16.5).

Type.-Adult male, No. 38031 Cleveland Museum of Natural History; Makinson's Grove, Avalon Peninsula, eastern Newfoundland; September 6, 1938; Raymond Hellmann and David C. Nutt, original number 293.

Geographic distribution.-Newfoundland.

Discussion.-Noble (1919) noted that specimens from western Newfoundland averaged browner, less grayish above and a richer buff on the sides than mainland birds, but considered the difference insufficient to warrant recognition of a distinct subspecies. It is our opinion, however, that a very well marked race is represented in Newfoundland with characters most pronounced in the eastern part of the island and specimens from the western part distinctly

* For Captain Robert A. Bartlett 
intermediate with $P$. a. atricapillus. In addition to the 7 specimens in fresh autumn plumage and 4 in worn summer plumage collected by our party on the Avalon Peninsula, there were made available to us by Mr. W. E. Clyde Todd of the Carnegie Museum and Mr. James L. Peters of the Museum of Comparative Zoology, 17 specimens in fresh autumn, worn breeding and immature plumages from western Newfoundland. For comparison with these we had a large series of specimens representing all seasonal plumages of $P$. a. atricapillus from Nova Scotia, New York, Northern Ohio, and Lake Nipissing, Ontario.

For comparison the measurements of the two other sub-species of black-capped chickadee that most closely resemble $P$. a. bartletti are here given.

P. a. atricapillus.-Adult male ( 6 winter specimens from northwestern New York): wing, 61.5-67 (average 64.5) mm.; tail, 58-65.5 (62); culmen, 8.5-10 (9.1); tarsus, 15-17 (15.9). Adult female ( 5 winter specimens from northwestern New York): wing, 62-66 (average 63.7) mm.; tail, 59-62.5 (60.7); culmen, 9-9.5 (9.2); tarsus, 15.5-16 (15.6).

P. a. occidentalis.-Adult male ( 14 autumn and winter specimens from western Oregon and southwestern British Columbia): wing, 59.5-64 (average 62.3) mm.; tail, 55.5-59.5 (56.9); culmen, 9-10 (9.5); tarsus, 14.5-17 (15.5). Adult female (5 autumn and winter specimens from western Oregon and southwestern British Columbia): wing, 58.5-61.5 (average 60.2) mm.; tail, 52.5-57 (54.9); culmen, 9-9.5 (9.2); tarsus, 15.5-17 (16.2).

This species is abundant in all thickets in eastern Newfoundland.

\section{Penthestes hudsonicus littoralis (Bryant). Acadian Chicka-} DEE.

Numerous small flocks of this species were observed at Makinson's Grove where 2 adult males were collected September 6, 1938, and 1 immature male July 5, 1939. It is not as generally common as the black-capped chickadee. 


\section{Certhia familiaris (subsp. ?). BRown CREEPER.}

Rooke (1935) reports seeing 3 brown creepers in the interior and obtaining 1 specimen on Beaver Brook in the Grand Falls region for the first authentic record from Newfoundland. Our party obtained 1 specimen on July 5, 1939, at Makinson's Grove and several others were heard both in July and upon returning in early September. It would seem that the Brown Creeper is not uncommon in the area about Makinson's Grove.

The single specimen obtained is similar to Anticosti Island specimens that are to be described as a new race by $\mathrm{F}$. W. Braund and E. P. McCullagh (manuscript) but is somewhat darker and more rufescent. It is very similar in color to $C$. $f$. zelotes of the Cascade Mountains of Oregon but smaller, particularly the bill.

With only 1 specimen available for study it would seem best for the present to refer Newfoundland brown creepers to the race soon to be described with type locality Anticosti Island. The only specimen in existence from Newfoundland besides ours is apparently the one taken by Rooke (1935) presumably now in the British Museum.

Nannus troglodytes hiemalis (Vieillot). EASTERN Winter WREN.

Brooks (1936) saw 1 at Salmonier and 1 was heard singing at Makinson's Grove, July 5, 1939.

Turdus migratorius nigrideus, subsp. nov. BLACK-BACKED Robin.

Local name: Robin Redbreast.

Subspecific characters. - Nearest Turdus migratorius migratorius, but darker throughout. Upper parts: gray areas darker, more blackish and black areas more extensive; wings and tail more blackish; back much darker, more blackish mouse gray, in males gray more or less completely obscured by an extension posteriorly of the black of the head. Lower parts: More deeply colored, hazel rather 
than cinnamon rufous, with white areas less extensive and black areas more extensive; in male, black streaks of throat tend to coalesce laterally and posteriorly; gray areas of under tail-coverts and under surface of tail darker; black spots on breast of juvenile specimens larger, tending to coalesce anteriorly.

Measurements.-Adult male ( 5 breeding specimens from Newfoundland): wing, 132-136 (average 134.30) mm.; tail, 102-107 (104.90); exposed culmen, 19-20 (19.60); tarsus, 31.5-36 (34.20). Adult female ( 8 breeding specimens from Newfoundland): wing, 123.5-131.5 (average 126.75) mm.; tail, 91-102 (96.75); exposed culmen, 18.5-20 (19.19); tarsus, 32-35 (33.19).

Type.-Adult male, 38037, Cleveland Museum of Natural History; Hodge Water, Avalon Peninsula, eastern Newfoundland; July 8, 1938; David C. Nutt, original number 159.

Geograpbic Distribution.-Breeds in Newfoundland. South in winter to eastern Canada and the eastern United States. Specimens have been seen from Nova Scotia, Wolfville, o $\sigma^{7}$, April 20; New York, Shelter Island, $\sigma^{\pi}$, March 28; Ohio, Geauga County, $\sigma^{\top}$, March 22, o, April 18. The robin is apparently partially a permanent resident in Newfoundland since natives report them to be common about St. John's in the winter months.

Remarks.-This is the most deeply colored of all the American robins and is an exceptionally well marked geographic race. The extremely blackish coloration of the head, neck and anterior back region sets it apart at a glance from all other known forms of Turdus migratorius. This melanistic tendency is equally well marked in male, female and juvenile specimens when compared with comparable specimens of the same sex and age from other parts of the species' range. Noble (1919) noted the darker color of Newfoundland robins but did not consider the difference worthy of recognition as a distinct subspecies. The characters of this new race seem to be more intense in eastern Newfoundland than in the western part of the island.

Specimens taken on the Avalon Peninsula include 3 males and 5 $\mathrm{f}$ cmales, all taken in July, but additional material from western Newfoundland was kindly lent by Mr. James L. Peters of the Muse- 
um of Comparative Zoology: Deer Lake, ㅇ ; Port au Port, ơ , 2 ㅇ; Nicholsville, $\sigma^{T}$. An excellent series of typical Turdus migratorius migratorius, including 16 specimens from Northern Ontario and Quebec, was available for comparison through the courtesy of Mr. W. E. Clyde Todd of the Carnegie Museum.

Turdus canadensis Müller (Systema Naturae Supplement, 1776, p. 140) was presumably based on breeding robins from the vicinity of Quebec, and that city is hereby fixed as its type locality. Since Quebec robins are like those from the rest of eastern Canada in differing as indicated above from the breeding population of Newfoundland, the name Turdus canadensis cannot be applied to birds of the latter region.

This robin is an abundant breeding bird on the Avalon Peninsula but is exceedingly wary as compared with its Ohio relatives. The noisy and precipitous departure of robins while the observer is still as much as 100 yards away is characteristic of birds of that region and elicited the quaint explanation from a resident of Brigus that "the foxes were after them"! This extreme wariness of the robin was also noted by Rooke (1935).

Hylocichla guttata faxoni Bangs and Penard. Eastern Hermit THRUSH.

The delightful song of this thrush was often heard issuing from the deepest spruce thickets in the early part of July. None were seen early in September.

Hylocichla ustulata swainsoni (Tschudi). Olive-BAcked THRUSH.

Rooke (1935) saw 1 near Grand Falls on August 21, and was given a specimen from the Avalon Peninsula by J. R. Ewing of St. John's.

Corthylio calendula calendula (Linnaeus). EASTERN RUBYCROWNED KINGLET.

Local name: Foxy Chub.

This tiny species was common, especially in early September 
when many flocks were noted flitting about the thicker spruce growths. A single adult male was collected at Hodge Water, July 7, 1938. Two immature specimens were taken at Makinson's Grove, September 6, 1938, and another September 1, 1939.

Anthus spinoletta rubescens (Tunstall). American Pipit.

Local name: Titlark.

Brooks (1936) records several in the breeding season from the hills overlooking the harbor of St. John's. Our party saw several on July 7, 1939, flitting about the cliffs overlooking Brigus harbor. The pipit would appear to be a common bird on the rocky coast of eastern Newfoundland, but Rooke (1935) found no sign of it in the interior.

Lanius borealis borealis Vieillot. Northern Shrike.

Rooke (1935) reports that a specimen of the northern shrike obtained from Avalon Peninsula was given to him by Mr. J. R. Ewing, a St. John's taxidermist. This is the only record of this species for Newfoundland.

Mniotilta varia (Linnaeus). BLAcK ANd White W

According to Rooke (1935) the black and white warbler is common in the interior, but it has yet to be reported from the Avalon Peninsula.

Dendroica aestiva amnicola Batchelder. Newfoundland YeLLOW W ARBLER.

Local name: Yellow-hammer.

This is a very common bird in the shrubby areas of the Avalon Peninsula. At Brigus and Hodge Water 5 breeding specimens were collected. Each year upon our return in the first week of September this species, as well as the rest of the warbler population of Avalon Peninsula, seems to have already migrated. On September 10, 1938, while at sea to the south of Newfoundland, a yellow warbler presumably from that island came on board the vessel. 
Dendroica coronata coronata (Linnaeus). MyrtLe Warbler.

This warbler is uncommon on the Avalon Peninsula, but would seem to be more common in the interior. A single specimen was collected at Makinson's Grove, on July 6, 1939.

\section{Dendroica breviunguis (Spix). BLACK-POLl Warbler.}

The black-poll appears to be the most abundant warbler on the Avalon Peninsula although considered rare in the interior of Newfoundland by Rooke (1935). In the low shrubby area at Hodge Water it was seen everywhere, while at Makinson's Grove it preferred the largest, most dense spruce.

On September 1, 1939, a lone female was collected at Makinson's Grove, apparently a straggler, as it is the only warbler recorded by our party during any of the September visits.

In all, 5 specimens were collected. Both male and female breeding specimens average somewhat darker (black streaks more extensive) than comparable specimens from Anticosti Island and Nova Scotia.

Dendroica palmarum hypochrysea Ridgway. YeLLow PALM WARBLER.

Reported by Rooke (1935) as common and generally distributed in the interior. He also records a specimen from the Avalon Peninsula given him for the British Museum by J. R. Ewing.

Seiurus noveboracensis noveboracensis (Gmelin). NORTHERN WATER-THRUSH.

This species is not common on the Avalon Peninsula. A pair was observed at Makinson's Grove on July 5 and its actions indicated that its nest was close by. Several other individuals were seen. Brooks (1936) states that it was still in song in early August.

The 2 breeding specimens collected are somewhat brighter yellow and more heavily streaked below than a comparable series from Nova Scotia. 
Geothlypis trichas brachidactyla (Swainson). NORTHERN YeLLOW-THROAT.

Although reported by Rooke (1935) as fairly common in the interior it has not been recorded definitely as yet from the east coast.

Wilsonia pusilla pusilla (Wilson). WiLson Warbler.

Local name: Yellow-hammer.

This warbler was found to be fairly common in the vicinity of Brigus and at Hodge Water where 3 breeding specimens were collected. It is one of the more common warblers of the Avalon Peninsula.

Setophaga ruticilla ruticilla (Linnaeus). American Redstart.

It is surprising that our party encountered only a few redstarts in view of the fact that Brooks (1936) reports them as almost as common as black-poll warblers. One female appeared to be nesting in Makinson's Grove.

Passer domesticus domesticus (Linnaeus). English Sparrow.

This introduced species is common in the streets of Brigus and on the docks at St. John's. Brooks found it common even at some distance from the latter city feeding in open fields with fox sparrows.

Euphagus carolinus (Müller). Rusty Blackbird.

Local name: Blackbird.

Several small flocks of rusty blackbirds were noted during the course of the field work but its occurrence was decidedly erratic. At Brigus, 2 specimens were taken July 6, 1937, and another was secured at Makinson's Grove, September 6, 1938.

Quiscalus aeneus Ridgway. Bronzed Grackle.

Griscom (1926) states that this species has been authentically recorded from near St. John's. 
Pinicola enucleator eschatosus Oberholser. NewfoundLand Pine Grosbeak.

Although reported as fairly common by Brooks (1936), this species was entirely unrecorded by our party on the Avalon Peninsula. Rooke (1935) collected 1 on August 18 in the Grand Falls region that was in breeding condition.

\section{Acanthis linaria linaria (Linnaeus). Common Redpolt.}

Brooks (1936) records the redpoll as very common. This was certainly not the case in the area covered by our expedition, since it went entirely unnoticed. Rooke (1935) saw a flock in the Grand Falls region on August 10 and September 10.

\section{Spinus pinus pinus (Wilson). Northern PINe Siskin.}

Brooks (1936) states that he saw many siskins in Bowring Park, St. John's, and according to Noble's (1919) report, it is apparently one of the commonest birds on the west side of Newfoundland. However, this species was not recorded either by Rooke (1935) from the interior or by our party in the Brigus region.

Loxia curvirostra pusilla Gloger. Newfoundland Red CRossBILL.

Flocks of red crossbills were a common sight at Makinson's Grove where they were evidently breeding. Some of these birds were to be seen flying recklessly about at almost all times and seeming to pay no attention to our party. An adult female and an immature male specimen were collected at Makinson's Grove, September 6, 1938, and an adult male on July 6, 1939.

Loxia leucoptera leucoptera Gmelin. American White-winged Crossbill.

The white-winged crossbill was likewise common at Makinson's Grove. The single adult male collected on September 6 was in breeding condition, and the plumage was rather worn. This 
specimen is of a deeper red and has more blackish flanks and under tail-coverts while an immature specimen taken September 1, 1939, is more blackish than any examples in a large series of male and immature white-winged crossbills from Nova Scotia. In this connection it is significant that Noble (1919) found a tendency toward blackishness in an adult and an immature specimen that he examined from western Newfoundland. It seems very likely that a larger series will show that the Newfoundland whitewinged crossbills are a distinct subspecies.

\section{Passerculus sandwichensis labradorius Howe. LABRADOR} Savannah Sparrow.

While a very common breeding bird in all open places on the Avalon Peninsula, the Savannah sparrow was especially abundant on the high flats overlooking Brigus harbor. In contrast to this, Rooke (1935) saw only a single individual in the interior of Newfoundland. The 13 specimens taken show that the breeding population of the Avalon Peninsula is perfectly typical of the Labrador race.

Junco hyemalis hyemalis (Linnaeus). Slate-colored Junco.

Juncos are recorded by Brooks (1936) as not common on the Avalon Peninsula and our expedition failed to record them at all. However, Rooke (1935) found them more commonly around habitations in the Grand Falls region of the interior.

Zonotrichia albicollis (Gmelin). White-throated Sparrow.

White-throats were fairly common at Hodge Water as elsewhere in the forested portion of the island, where their songs were often heard coming from the dense spruce growth. In July 1939, at Makinson's Grove, a continual chorus of their clear ringing notes issued from the woods night and day. Several calls were heard even during a heavy downpour on the morning of July 6, on which day a single female bird was collected. On September 10, 1933, while off the southwestern coast of Newfoundland, a migrating white-throated sparrow came aboard the vessel. 
Passerella iliaca iliaca (Merrem). EAstern Fox Sparrow.

Local name: Labrador sparrow.

The fox sparrow is an abundant breeding bird on the Avalon Peninsula. In early July singing males appeared to occupy the tips of practically every prominent spruce, and were in almost continuous song. However, they were very shy and could not be approached closely. Two breeding males and 2 juvenal birds were collected. Judging from Rooke's (1935) experience, fox sparrows are apparently less common in the interior of eastern Newfoundland than near the coast.

Melospiza lincolni lincolni (Audubon). Lincoln Sparrow.

Although recorded by Brooks (1936) as common on the "barrens" of the Avalon Peninsula, and as fairly common by Rooke (1935) in the interior of Newfoundland, the Lincoln sparrow was rare in the region traversed by our expedition.

Melospiza georgiana georgiana (Latham). EASTERn Swamp SPARROW.

The Swamp sparrow is by far the most abundant bird observed in the vicinity of Brigus. At the time of the field work there in July, the behavior of these birds indicated nesting activities since, if approached nearer than 50 yards, they ceased singing and continued with high pitched scolding notes from the depths of the underbrush. Their favorite haunts were the wet flats covered by low bog shrubs.

Brooks (1936) also found this species common on the Avalon Peninsula, although strangely enough less common than the Lincoln sparrow. Rooke (1935) found the swamp sparrow localized in one marshy area in the Grand Falls region where it inhabited wetter places than the Lincoln sparrow.

The 5 breeding specimens and 1 autumn plumaged bird collected are apparently intermediate between georgiana and ericrypta, but somewhat nearer the former race. 


\section{BIBLIOGRAPHY OF NEWFOUNDLAND BIRDS}

American Ornithologists Union 1931. Check List of North

American Birds (fourth edition). Lancaster, Pa., pp. 1-526.

Arnold, E. 1912. A Short Summer Outing in Newfoundland, 1911. Auk, Vol. 29, No. 1, pp. 72-79.

Austin, O. L. Jr. 1932. The Birds of Newfoundland Labrador. Memoirs of the Nuttall Ornithological Club, No. 7, pp. 1-229 Map.

Batchelder, C. F. 1908. The Newfoundland Hairy Woodpecker. Proceedings of the New England Zoological Club, Vol. 4, pp. $37-38$.

1918. Two Undescribed Newfoundland Birds. Proceedings of the New England Zoological Club, Vol. 6, pp. 81-82.

Bent, A. C. 1912. A New Subspecies of Crossbill from Newfoundland. Smithsonian Institution Miscellaneous Collection, Vol. 60, No. 15, pp. 1-3.

Brewster, W. 1885. The Rock Ptarmigan of Newfoundland. Auk, Vol. 2, No. 2, pp. 193-195.

........1906. Occurrence of the Lapwing and the Turkey Buzzard in Newfoundland. Auk, Vol. 23, No. 2, p. 221.

Brooks, E. A. 1936. Observation of Some Newfoundland Birds. Auk, Vol. 53, No. 3, pp. 342-345.

Brown, W. J. 1911. Some Newfoundland Bird Notes. Ottawa Naturalist, Vol. 25, pp. 89-94.

1912. Additional Notes on the Birds of Newfoundland. Ottawa Naturalist, Vol. 26, pp. 93-98. 
1912. Unusual Nesting Site of the Pigeon Hawk in Newfoundland. Ottawa Naturalist, Vol. 26, pp. 70-71.

Chapman, F. M. 1932. Handbook of Birds of Eastern North America. D. Appleton and Co., NewYork and London, pp. 1-581.

English, A. 1918. A Gannet Colony. Ottawa Naturalist, Vol. 32, p. 198.

Gilliard, E. T. 1937. The Gannets of Funk Island. Auk, Vol. 54, No. 3, pp. 379-381.

Griscom, L. 1926. Notes on the Summer Birds of the West Coast of Newfoundland. Ibis, twelfth series, Vol. 2, No. 4, pp. 656-684.

Gross, A. O. 1937. Birds of the Bowdoin-MacMillan Arctic Expedition, 1934. Auk, Vol. 54, No. 1, pp. 12-42. pl. 2-5.

Howe, R. H. Jr. 1900. A New Subspecies of the Genus Hylocichla. Auk, Vol. 17, No. 3, pp. 270-271.

1913. A few Notes on Newfoundland Birds. Auk, Vol. 30, No. 1, pp. 114-115.

Ingersoll, E. 1928. Lapwings Invade Newfoundland and Canada. Auk, Vol. 45, No. 2, pp. 208-210.

Lewis, H. F. 1922. The Mourning Dove in Newfoundland. Auk, Vol. 39, No. 1, pp. 106-107.

Lloyd, Hoyes 1939. Banded Kittiwake from Russia recovered in Newfoundland. Canadian Field Naturalist, Vol. 53, No. 2, pp. 29-30.

Lucas, F. A. 1890. The Expedition to Funk Island with Observations upon the History and Anatomy of the Great Auk. Annual Report of the Smithsonian Institution, U. S. National Museum, 1887-1888, pp. 493-529. 
Noble, G. K. 1919. Notes on the Avifauna of Newfoundland. Bulletin of the Museum of Comparative Zoology, Vol. 62, No. 14, pp. 543-568.

Oberholser, H. G. 1914. Four New Birds from Newfoundland. Proceedings of the Biological Society of Washington, Vol. 28, pp. 43-45.

Porter, L. H. 1900. Newfoundland Notes. Auk, Vol. 17, No. 1, pp. 71-73.

Reeks, H. 1869. Notes on the Zoology of Newfoundland. Zoologist, 2nd series, Vol. 4, pp. 1609-1614; 1689-1695; 1741-1759; 1849-1858.

Rooke, K. B. 1935. Observation on the Birds of Newfoundland during the 1934 Expedition of the Public Schools Exploring Society. Ibis, thirteenth series, Vol. 5, No. 4, pp. 856-879.

Stejneger, L. 1884. A New Subspecies of Willow Grouse from Newfoundland. Auk, Vol. 1, No. 4, p. 369.

Stuart, G. H., 3rd. 1920. Nesting of the Greater Yellow-legs in Newfoundland. Auk, Vol. 37, No. 2, p. 292.

Wynne-Edwards, V.C. 1935. The Newfoundland Gannet Colony; with Recent Information on the other North American Gannetries. Ibis, thirteenth series, Vol. 5, No. 3, pp. 584-594. 


*110 $10^{0}$ 


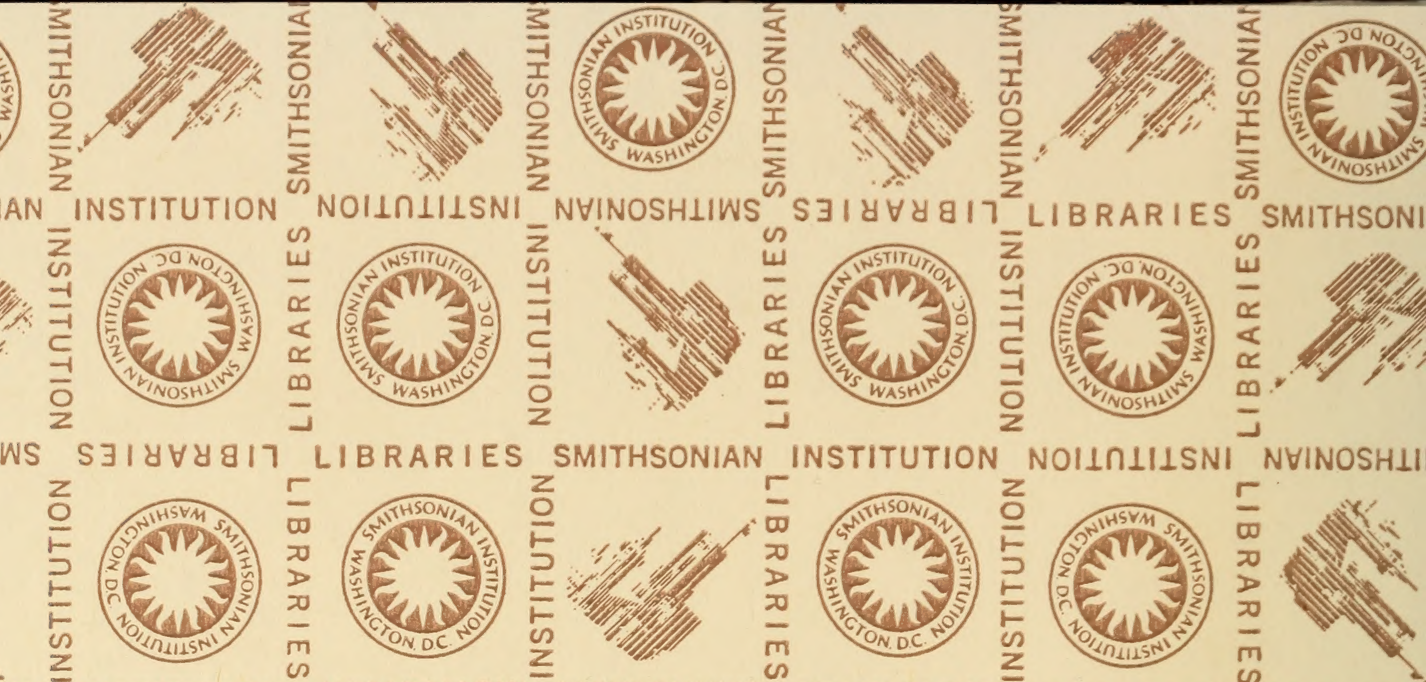

NHINOSHII

IAN INSTITUTION
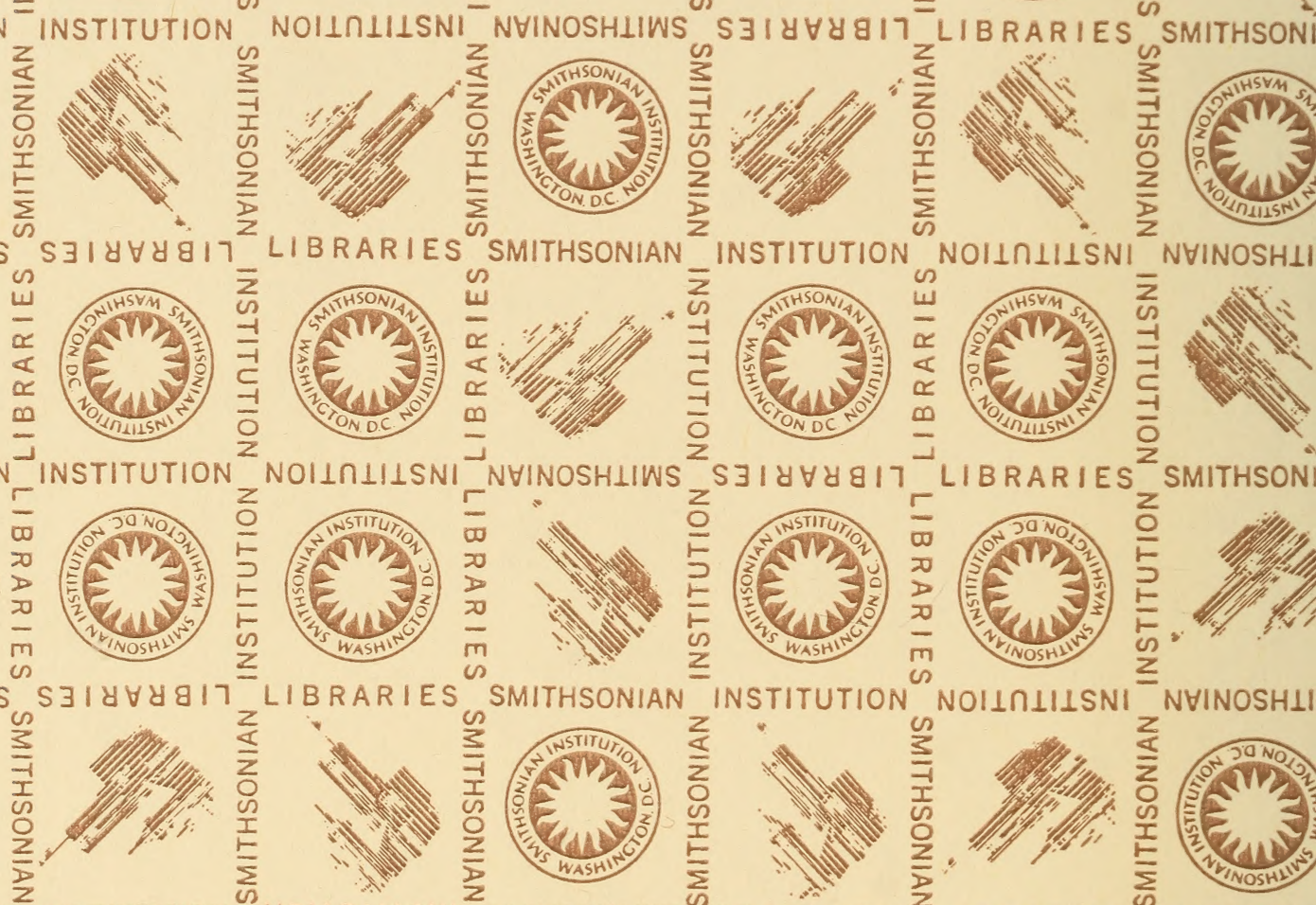

SMITHSON
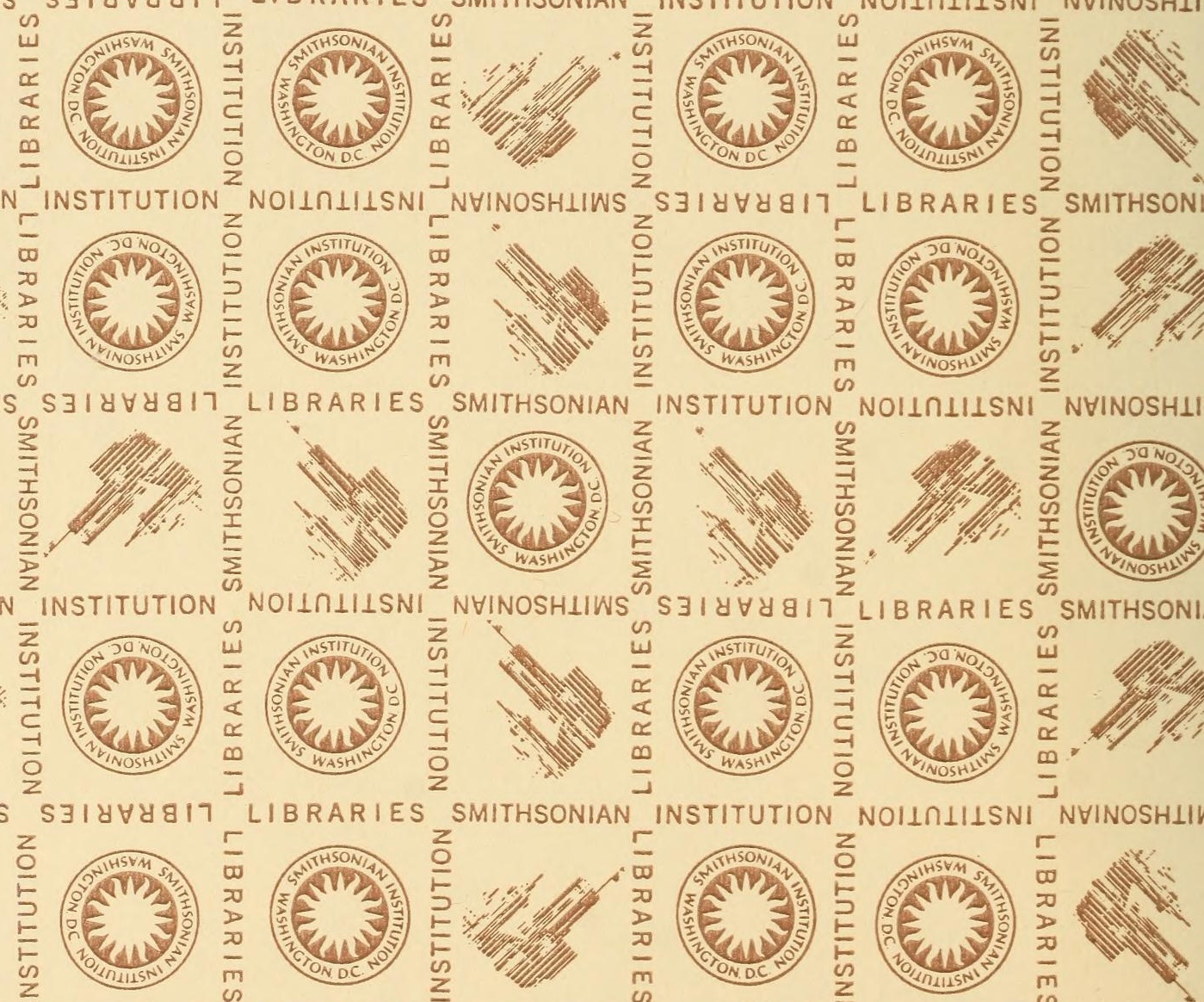

LIBRARIES SMITHSONIAN

INSTITUTION
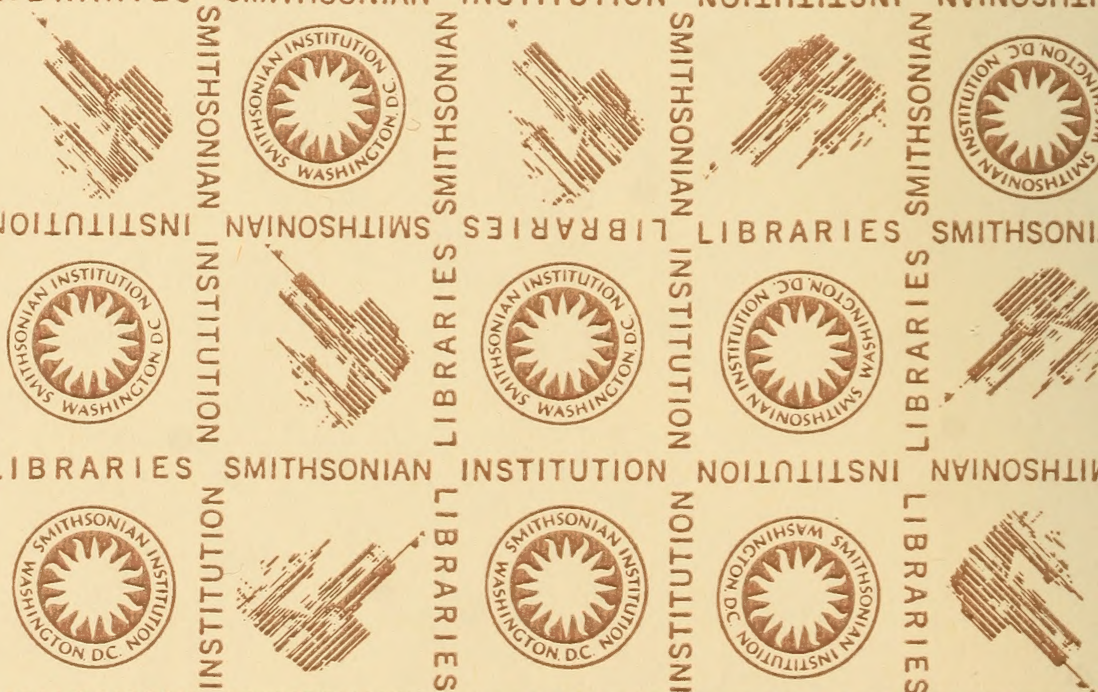

AN INSTITUTION

NOILOIISNI

s

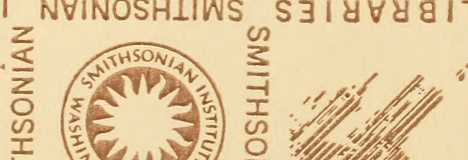

$\sum_{\substack{2 \\ 0 \\ 0}}^{2}$

SMITHSONI

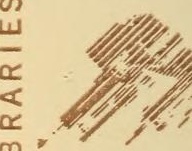

NVINOSHIIV 


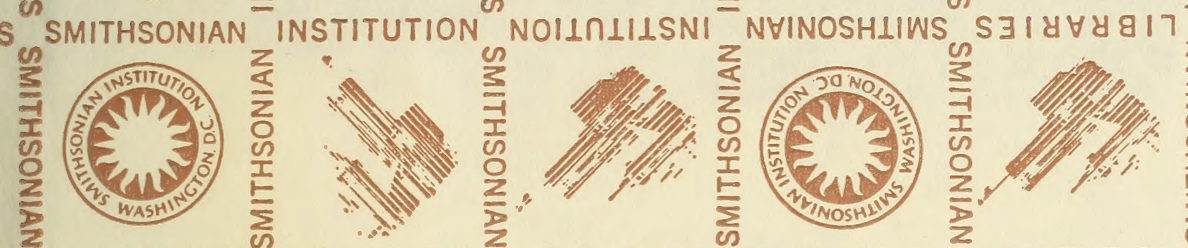

II NHINOSHLINS
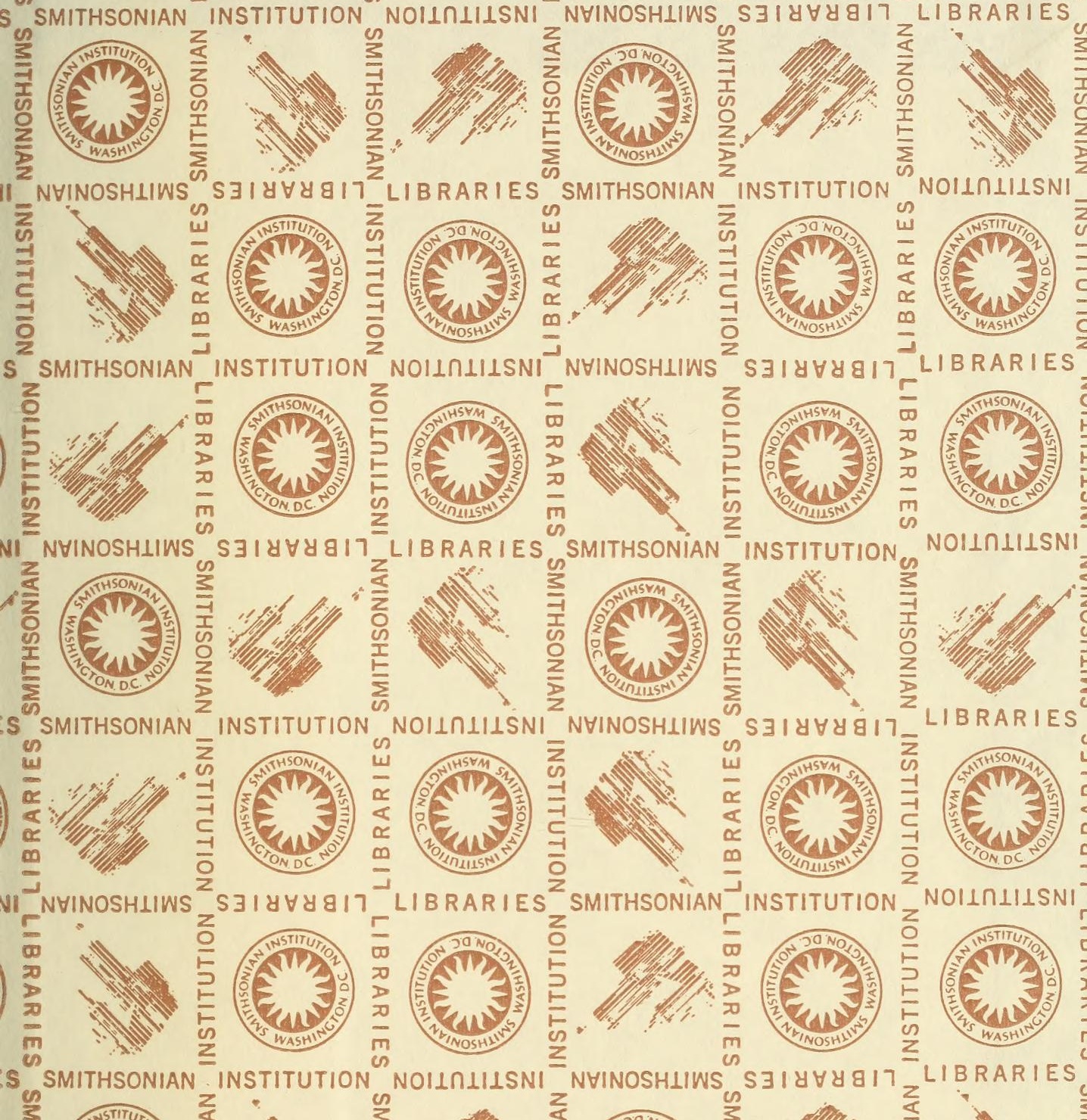

SMITHSONIAN
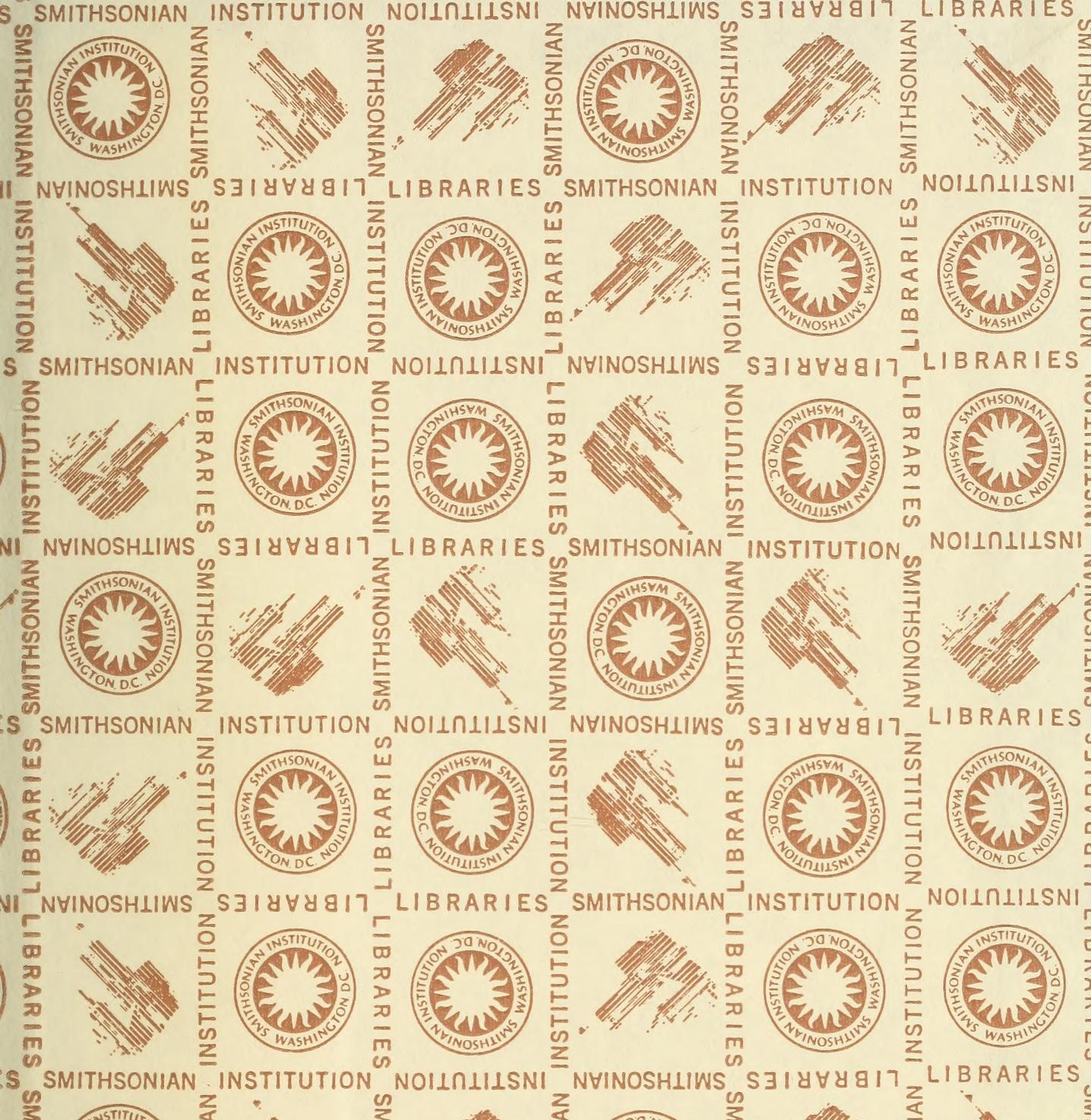

LIBRARIES
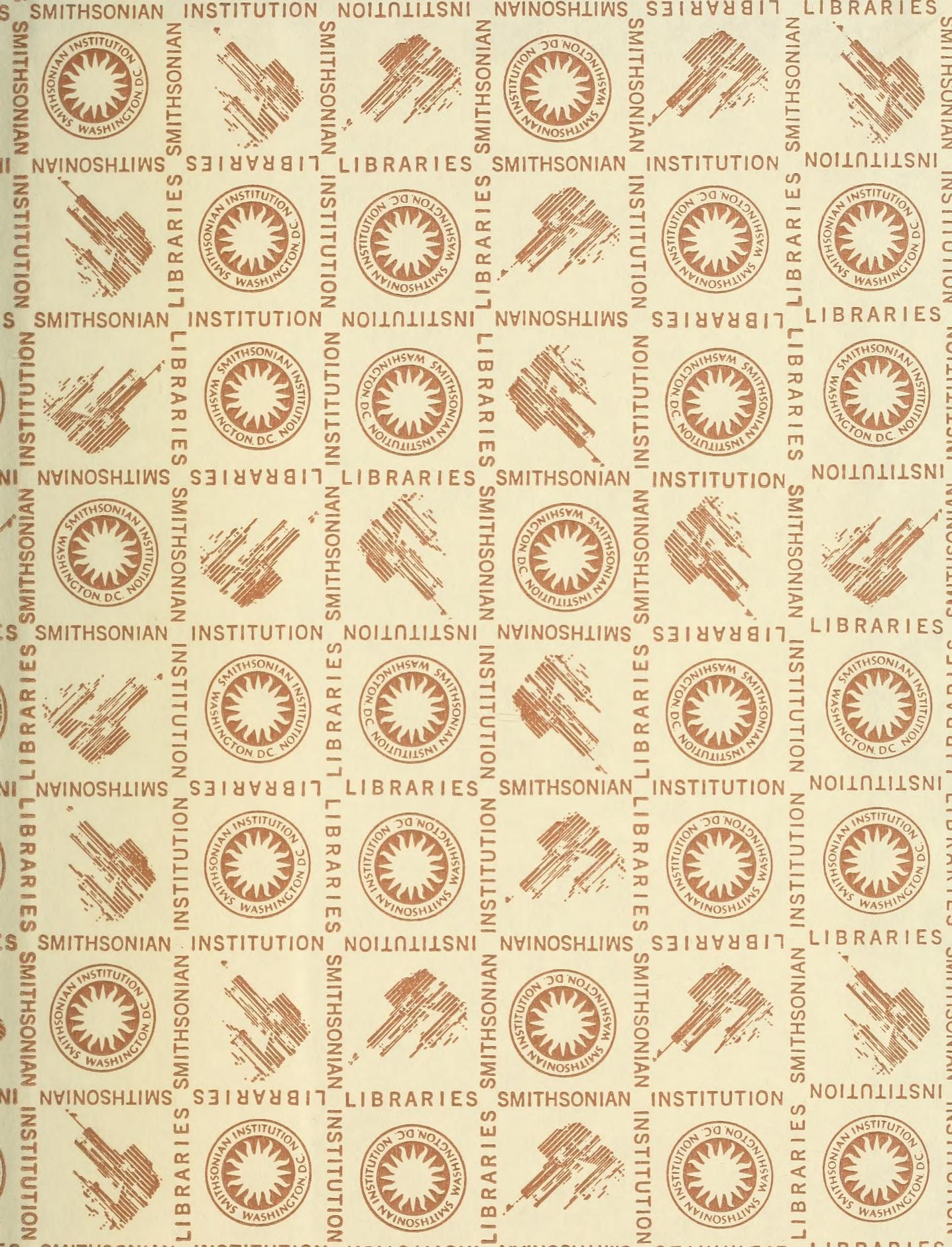

NOIINIIISNI

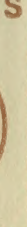

SMITHSONIAN
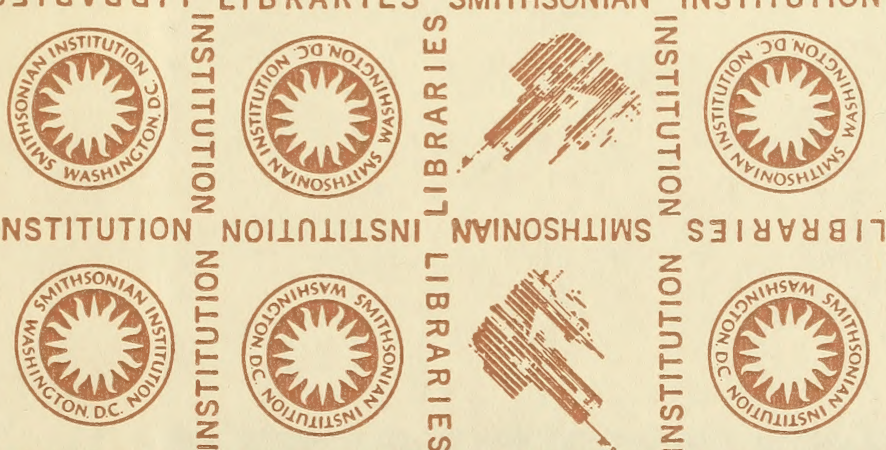

NOIINIILSNI
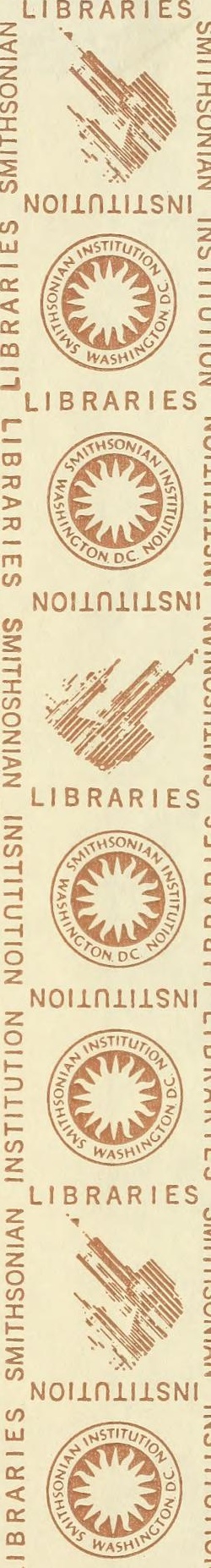

LIBRARIES

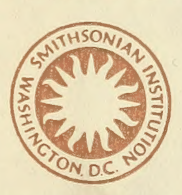

NOILIIISNI 
